\title{
PENGARUH SENAM NIFAS TERHADAP PROSES INVOLUSI UTERI PADA IBU POSTPARTUM
}

\author{
IKA NUR SAPUTRI ${ }^{1}$, RAHMAD GURUSINGA ${ }^{2}$, NURMAILANI FRISKA ${ }^{2}$ \\ ${ }^{1}$ Institut Kesehatan Medistra Lubuk Pakam \\ Jl. Sudirman No 38 Lubuk Pakam \\ e-mail: ikanursaputri@gmail.com
}

DOI : https://doi.org/10.35451/jkk.v2i2.347

\begin{abstract}
Postpartum hemoragic is caused by unfavorable uterine involution, therefore early ambulation with puerperal gymnastics is necessary. Puerperal gymnastics is one way for early mobilization that is highly recomended for post partum mothers so that the process of involution is smooth. The purpose of the study was to determine the effect of puerperal gymnastics by uterine involution in post partum in midwife clinick Nining Pelawati in lubuk pakam sub-district with terrain city in 2019. The research medhod is a pre-experiment with respondent totaling 30 normal post partum mothers at the seka sriwahyuni midwife clinic consisting of 15 morhers who performed puerperal gymnastics (eksperimental respondent group). And 15 mothers who did not do purperal gymnastics (group of control respondents). Data collection uses observation while the formula uses the dependent $t$-test, the results of the study of the speed of uterine involution in mothers who do puerperal gymnastics are mostly in the fast category as much as 8 people $(53,3 \%)$, the rest are in the normal categori as many as 5 people $(33,3 \%)$, while those in the slow category do not exit $(0,00 \%)$. The rate of uterine involution in pospartum women who do not do partuirition gymnastics in the majority in the slow category in 9 people $(60,6 \%)$, the rest are in the normal category as 4 people $(26,6 \%)$, while in the fast category as many as 2 people $(13,3 \%)$. It can be concluded differences in changen in uterine involution between intervention groups ang control groups.
\end{abstract}

Keywords: Puerperal Exercise, Speed of Uterine Involution, Postpartum.

\section{PENDAhuluan}

Menurut definsi WHO (World Health Organization), pada tahun 2012 angka kemataian ibu di dunia 287.000, WHO memperkirakan 500.000 kematian ibu melahirkan di seluruh dunia setiap tahunnya, penyumbang terbesar dari angka tersebut merupakan negara berkembang yaitu $99 \%$. Diseluruh dunia setiap menitnya setiap wanita meninggal karena komplikasi yang terkait dengan kehamilan, persalinan dan masa nifas dengan kata lain, 1.400 wanita meninggal setiap hari atau lebih dari 500.000 setiap tahun (World Health Organization, 2012).

Angka kematian ibu dan bayi merupaka $n$ salah satu indikator untuk mengukur kualitas program kesehatan dan derajat kesehatan masyarakat di suatu negara. Target Millenium Develoment Goals (MDG's) adalah penurunan $75 \%$ rasio kematian maternal pada tahun 2015. Pencapaian tersebut sangat sensitif terhadap pemilihan indikator kematian maternal 
(Adriaansz, 2007). Indonesia merupakan salah satu negara yang memiliki angka kematian ibu yang cukup tinggi. Angka kematian ibu di indonesia mencapai 248 kematian per 100.000 kelahiran hidup (SDKI, 2012).

Berdasarkan data tahun 2016, jumlah angka kematian ibu melahirkan dan masa nifas di sumut mencapai 5.000 orang perminggu. Faktor kematian ibu disebabkan faktor perdarahan, hipertensi juga infeksi,jumlah angka kematian ibu melahirkan dan masa nifas tersebut mengalami penurunan dari tahun 2016 yakni 240 jiwa. Begitu juga dengan angka kematian bayi di tahun 2017 ada 1.062 turun dari 1.080 di tahun 2016 (Profil Kesehatan Provinsi Sumatera Utara, 2017).

$$
\text { Menurut Adriaansz (2007) }
$$

sebagian besar kematian maternal terjadi pada trimester ketiga kehamilan, dan minggu pertama setelah persalinan. Kematian ibu maternal banyak terjadi karena adanya komplikasi post partum yaitu perdarahan $(28 \%)$, eklamsia $(24 \%)$, infeksi $(11 \%)$, dan partus macet atau lama (5\%). Perdarahan post partum merupakan penyebab kematian yang paling sering terjadi, pengenalan periode kritis dalam kehamilan, persalinan dan nifas akan membawa manfaat bagi efisiensi sumber daya dan efektifitas upaya yang akan dijalankan untuk memperbaiki kesehtan ibu, bayi dan anak.

Gangguan masa nifas salah satunya yaitu proses pemulihan kondisi fisik ibu postpartum yaitu proses involusi uteri. Gangguan proses involusi yang tidak sempurna diantaranta adalah subinvolusi yang dapat mengakibatkan perdarahan dan kematian ibu. Kebanyak ibu nifas segan untuk melakukan pergerakan, karena mereka khawatir gerakan yang dilakukan justru menimbulkan dampak seperti nyeri dan perdarahan, sehingga masih banyak ibu-ibu nifas yang takut bergerak dan menggunakan sebagian waktunya untuk tidur terus-menerus (Marmi,2017).

Berdasarkan survey pendahuluan pada tanggal 03 April 2019 di Klinik Bidan Nining Pelawati Kecamatan Lubuk Pakam.Klien terdapat 15 orang ibu bersalin. Hasil wawancara pada $10 \mathrm{ibu}$ postpartum terdapat 7 ibu postpartum yang melakukan senam nifas mengalami involusi uteri secara normal, sedangkan yang tidak melakukan senam nifas mengalami subinvolusi uteri sebanyak 3 orang ibu postpartum. Alasan ibu postpartum tidak melakukan senam nifas karena takut sakit dan nyeri pada luka jahit. Berdasarkan uraian di atas maka peneliti tertarik untuk mengangkat masalah tersebut ke dalam penelitian yang berjudul "Pengaruh Senam Nifas Dengan Terjadinya Proses Involusi Uteri Pada Ibu post Patum Di klinik Nining Pelawati Kecamatan Lubuk Pakam Kabupaten Deli Serdang Tahun 2019".

\section{METODE}

Jenis penelitian ini yang digunakan yaitu quasy eksperiment yaitu untuk mengidentifikasi pengaruh senam nifas terhadap involusi uteri. Desain ini menggunakan dua kelompok yaitu kelompok eksperimen dan kelompok kontrol kedua kelompok tersebut diberikan pretest. Kelompok eksperimen diberikan senam nifas sedangkan kelompok kontrol tidak dilakukan senam nifas. Populasi dalam penelitian ini adalah semua ibu nifas dengan persalinan normal wilayah klinik bidan Eka Sriwahyuni sebanyak 30 orang. Penelitian ini mengambil sampel dilakukan dengan menggunakan accidental sampling.

Analisa data pada analisi univariat data yang diperoleh dari hasil pengumpulan data dapat disajikan bentuk tbel distribusi frekuensi frekuensi. Pengujiannya dilakukan menggunakan Mann Whitney $U$.

\section{HASIL}

1. Distribusi responden berdasarkan kecepatan Involusi Uteri yang melakukan senam nifas.

\begin{tabular}{ccc}
\hline $\begin{array}{c}\text { Involusi } \\
\text { Uteri }\end{array}$ & $\mathrm{n}$ & $\begin{array}{c}\text { Presentase } \\
(\%)\end{array}$ \\
\hline Lambat & 0 & 0,00 \\
Cepat & 10 & 66,6 \\
Normal & 5 & 33,3 \\
\hline Total & 15 & 100,0 \\
\hline
\end{tabular}


Berdasarkan tabel diatas dapat diketahui bahwa kecepatan involusi uteri pada ibu post partum yang melakukan senam nifas (kelompok eksperimen) di klinik Nining Pelawati mayoritas berada pada kategori cepat sebanyak 10 orang $(66,6 \%)$, sisanya berada pada kategori normal sebanyak 5 orang $(33,3 \%)$, sedangkan yang berada dikategori lambat tidak ada $(0,00 \%)$.

2. Distribusi respoden berdasarkan kecepatan involusi uteri yang tidak melakukan senam nifas.

\begin{tabular}{ccc}
\hline $\begin{array}{c}\text { Involusi } \\
\text { Uteri }\end{array}$ & $\mathrm{n}$ & $\begin{array}{c}\text { Presentase } \\
(\%)\end{array}$ \\
\hline Lambat & 9 & 60,0 \\
Cepat & 2 & 13,3 \\
Normal & 4 & 26,6 \\
\hline Total & 15 & 100,0 \\
\hline
\end{tabular}

Berdasarkan tabel diatas dapat diketahui bahwa kecepatan involusi uteri pada ibu post partum yang tidak senam nifas (kelompok kontrol) di klinik Nining Pelawati mayoritas berada pada kategori lambat sebanyak 9 orang $(60,6 \%)$, sisanya berada pada kategori normal sebanyak 4 orang $(26,6 \%)$, sedangkan yang berada dikategori cepat sebanyak 2 orang $(13,3 \%)$.

3. Pengaruh senam nifas terhadap proses involusi uteri

\begin{tabular}{ccccc}
\hline $\begin{array}{c}\text { Kelompo } \\
\mathrm{k}\end{array}$ & $\mathrm{n}$ & Mean & $\begin{array}{c}\text { Std. } \\
\text { Deviatio } \\
\mathrm{n}\end{array}$ & $\mathrm{P}$ \\
\hline $\begin{array}{c}\text { Ikut } \\
\text { senam } \\
\text { nifas }\end{array}$ & 1 & 2,33 &, 488 &, 00 \\
Tidak & 1 & 1,93 & 1,335 & \\
ikut & 5 & & & \\
senam \\
nifas
\end{tabular}

Berdasarkan tabel diatas dapat digambarkan rata-rata kelompok yang ikut senam nifas adalah $2,33 \mathrm{~cm}$ dengan SD ,488 cm sedangkan kelompok yang tidak iku senam nifas yaitu $1,93 \mathrm{~cm}$ dengan SD 1,335 cm. Hasil uji statistik diperoleh nilai $\mathrm{p}=, 000$ maka dapat disimpulkan bahwa ada perbedaan yang signifikan terhadap perubahan involusi uteri antara kelompok intervensi dan kelompok kontrol.

\section{PEMBAHASAN}

Asuhan essensial diperlukan pada ibu postpartum agar dapat mengoptimalkan kontraksi uterus dalam membantu proses involusi uteri, salah satunya dengan melaksanakan senam nifas. Senam nifas merupakan aktifitas atau latihan peregangan otot yang dilakukan setelah melahirkan meliputi ambulasi dini dan latihan fisik yang dimulai dari latihan yang sederhana dilanjutkan dengan latihan yang lebih berat. Senam nifas adalah senam yang dilakukan ibu setelah melahirkan yang bertujuan untuk meningkatkan dan mempertahankan sirkulasi ibu pada masa nifas, serta membantu proses involusi uteri (Marmi, 2015).

Hasil penelitian menunjukkan bahwa ada pengaruh senam nifas terhadap penurunan tinggi fundus uteri (Andriyani, dkk., 2013; Rullynil, dkk., 2014).

Setelah persalinan tubuh seseorang ibu akan memasuki masa pemulihannya dan perlahan kembali ke kondisi sebeleum hamil. Tindakan senam nifas membantu proses fisiologi ini seara perlahan. Umumnya yang menjadi perhatian ibu selama senam nifas adalah bagaimana memulihkan bentuk tubuh dan dinding perut sediakala. Sehingga dengan melakukan senam nifas bentuk tubuh dan perut akan kembali seperti sediakala.

Hasil penelitian ini juga didukung dengan penelitian yang dilakukan pada 1003 wanita yang mengikuti program senam nifas dengan latihan yang teratur mengalami pengerutan pada rahim yang lebih cepat. Dan dalam studi dari 1432 ibu nifas diswedia yang melakukan senam nifas ditemukan bahwa mayoritas $71 \%$ wanita tersebut mengalami metabolisme tubuh yang lancar dan pemulihan fisik yang lebih cepat.

Adapun manfaat senam nifas diantaranya adalah membantu proses involusi uteri, memperbaiki sirkulasi darah, sikap tubuh dan punggung setelah melahirkan, memperbaiki tonus otot, pelvis dan perenggangan otot abdomen serta memperkuat otot panggul (Marmi, 2015).

Penelitian yang dilakukan oleh dr. Ira kusyairi dipl, pt. Fisioterapis dari 
RSAB arapan kita jakarta, mejelaskan bahwa dengan dilakukan senam nifas mampu mengencangkan otot rahim, kondisi umum ibu menjadi lebih baik, pemulihan lebih cepat, kemungkinan terkena infeksi sangat kecil karena sirkulasi darah yang bagus, memulihkan dan menguatkan otot-otot punggung, otot dasar panggul dan otot.

Hasil penelitian Sulistyawati dan Khasanah (2017) dijelaskan bahwa lebih dari $50 \%$ responden yang sering melakukan senam nifas mengalami involusi uteri yang cepat sebanyak 9 $(52,9 \%)$ responden, sedangkan sisanya sering melakukan senam nifas tapi mengalami involusi uteri yang lambat.Berdasarkan uji Fisher Exact Probability pada $\mathrm{a}=0,05$ didapatkan nilai $\mathrm{P}=0,02$ karena $\mathrm{P}<0,05$ maka $\mathrm{HO}$ ditolak artinya terdapat hubungan antara senam nifas dan involusi uteri Uteri pada ibu postpartum di wilayah kerja puskesmas Tawangsari Kabupaten Mojokerto.

\section{KESIMPULAN}

a. Rerata produksi ASI sebelum dilakukan pijat oksitosin adalah 9,90.

b. Rerata produksi ASI sesudah dilakukan pijat oksitosin adalah 13,50

c. Ada pengaruh yang signifikan terhadap produksi ASI sebelum dan sesudah dilakukan pijat oksitosin pada Ibu Postpartum di Klinik Pratama Nining Pelawati Tahun 2019 dengan nilai $p$-value $=0,008$ $(p \leq 0,05)$.

\section{DAFTAR PUSTAKA}

Arma, N., et.al, (2017). Asuhan Kebidanan. Medan

Asih, Yusari, (2017). "Pengaruh Pijat Oksitosin terhadap Produksi ASI pada Ibu Nifas". Jurnal Keperawatan. Volume XIII, No. 2, Oktober 2017. Diperoleh dari www.googlescolar.co.id. Diakses pada tanggal 02 Mei 2019.

Astutik, R.Y., (2017). Payudara dan Laktasi. Jakarta : Salemba Medika.
Azriani, D dan Handayani S, (2016). 'The Effect of Oxytocin Massage on Breast Milk Production'. Dama Internasional Journal of Researchers. Vol 1, 8 August 2016, hal 47-50. Diperoleh dari www.googlescolar.com. Diakses pada tanggal 22 Mei 2019.

Delima, M, Arni GZ, Rosya E, (2016). "Pengaruh Pijat Oksitosin Terhadap Peningkatan Produksi ASI Ibu Menyusui Di Puskesmas Plus Mandiangin". Jurnal IPTEKS Terapan. Volume 9. I4, 282-293. Diperoleh dari www.googlescolar.co.id. Diakses pada tanggal, 01 April 2019.

Global Breastfeeding Scorecard, 2018. Diperoleh dari https://www.who.int/nutrition/pub lications/infantfeeding/global-bfscorecard-2018. pdf?ua=1. Diakses pada 10 Mei 2019.

Guyton, A.C. (2008). Buku Ajar Fisiologi Kedokteran. Edisi 11. Jakarta: EGC

Hastono, S.P., (2016). Analisis Data Pada Bidang Kesehatan. Jakarta: Rajawali Pers.

Kiftia, Mariatul, (2015). "Pengaruh Terapi Pijat Oksitosin Terhadap Produksi ASI pada Ibu Post Partum". Jurnal Ilmu Keperawatan. Volume 3, No. 1. 2015. Hal. 42-49 Diperoleh dari www. www.googlescolar.co.id. Diakses pada tanggal 01 Mei 2019.

Maita, Liva, (2016). "Pengaruh Pijat Oksitosin terhadap Produksi ASI". Jurnal Penelitian Kesehatan Suara Forikes. Volume VII Nomor 3, Juli $2016 . \quad$ Diperoleh dari www.googlescolar.co.id. Diakses pada tanggal 01 April 2019.

Notoatmodjo, Soekidjo, (2015). Metodologi Penelitian Kesehatan. Jakarta : Rineka Cipta.

Notoatmodjo, S., (2015). Metode Penelitian Kesehatan. Jakarta : Rineka Cipta.

Rahayu, Anik Puji, (2019). Panduan Pratikum Keperawatan Maternitas. Yogyakarta: Deepublish.

Rahayu D dan Yunarsih, (2018). "Penerapan Pijat Oksitoksin dalam Meningkatkan Produksi ASI Ibu 
Postpartum". Journals of Ners Community. Volume 09, nomor 01, Juni 2018. Hal 08-14. Diperoleh dari www.goglescolar.com. Diakses pada tanggal 05 April 2019.

Rahayuningsih, T, Mudigdo A, Murti B, (2016)."Effect of Breast Care and Oxytocin Massage on Breast Milk Production: A study in Sukoharjo Provincial Hospital". Journal of Maternal and Child Health. Volume 1 nomor 2, 2016, halaman 101109. Diperoleh dari www.googlescolar.com. Diakses pada tanggal 22 Mei 2019.

Rukiyah, AY, et all, (2015). Asuhan Kebidanan III (Nifas). Jakarta : CV. Trans Info Media.

Pilaria E dan Sopiatun R, (2017). "The Effect of Oxytocin Massage on Postpartum Mother Breast Milk Production at Pejeruk Public Health in the Year of 2017". Jurnal Kedokteran YARSI.Volume 26 Nomor 1. Hal 027-033 (2018). Diperoleh dari www.googlescolar.com. diakses pada tanggal 07 Mei 2019.

Profil Kesehatan Indonesia Tahun 2017 diakses pada 25 Maret 2019.

Profil Kesehatan Provinsi Sumatera Utara Tahun 2017 diakses pada 25 Maret 2019.

Wijayanti dan Setyaningsih, (2017). "Perbedaan Metode Pijat Oksitosin dan Breast Care Dalam Meningkatkan Produksi ASI Pada Ibu Post Partum ". Jurnal Komunikasi Kesehatan .Vol.VIII No.2 Tahun 2017. Hal. 1-12. Diperoleh dari www. www.googlescolar.co.id. Diakses pada tanggal 01 April 2019.

Wulandari, FT, Aminin F, Dewi $U$, (2014). "Pengaruh Pijat Oksitosin Terhadap Pengeluaran Kolostrum Pada Ibu Post Partum Di Rumah Sakit Umum Daerah Provinsi Kepulauan Riau". Jurnal Kesehatan. Volume V, Nomor 2, Oktober 2014, hlm 173-178. Diperoleh dari www.googlescolar.co.id. Diakses pada tanggal 01 April 2019. 